\title{
コンクリート構造物の長期性能照査技術
}

\author{
宮里 心一*1・野口 貴文*2 $\cdot$ 武若 耕司*3
}

1.はじめに

耐用年数まで構造物の性能が要求值を下回ることの無 いよう，環境作用を考慮して長期性能を照査することが 重要である。したがって, 最新の研究成果も含んだ, 科 学的メカニズムに基づく精緻なモデルによって, 実用的 な耐久性照査が可能になることが望まれる。さらに，腐 食速度を予測し，腐食ひび割れ発生の時期を解析できれ ば，進展期の終焉を要求性能に設定した耐久性照査も可 能になる。

以上の背景を踏まえて, 日本コンクリート工学協会 (JCI)「コンクリート構造物の長期性能シミュレーショ ンソフト作成委員会（以下，「劣化ソフト作成委員会」 と称す)」卓は, (株計算力学研究センターの協力を得て, コンクリート構造物の長期性能をシミュレーションするソ フト「LECCA (Life time Evaluation Program for Concrete Structures by Computational Analysis) シリーズ」 を開発した。これは、コンクリート構造物の長寿命化の ための設計や維持管理に必要な情報を予測するための支

表-1 JCl 劣化ソフト作成委員会 劣化評価 WG メンバー

\begin{tabular}{|c|l|l|}
\hline & 氏 名 & \multicolumn{1}{|c|}{ 現所属 } \\
\hline 委員長 & 武若耕司 & 鹿児島大学 \\
\hline 主査 兼 幹事 & 野口貴文 & 東京大学 \\
\hline 幹 事 & 山口明伸 & 鹿児島大学 \\
\hline 副 査 & 宮里心一 & 金沢工業大学 \\
\hline \multirow{5}{*}{} & 井元晴丈 & BASF ポゾリス \\
\cline { 2 - 3 } & 加藤佳孝 & 東京理科大学 \\
\cline { 2 - 3 } & 桂 修 & 北方建築総合研究所 \\
\cline { 2 - 3 } & 兼松 学 & 東京理科大学 \\
\cline { 2 - 3 } & 斎藤 豪 & 東京工業大学 \\
\cline { 2 - 3 } & 斉藤成彦 & 山梨大学 \\
\cline { 2 - 3 } & 堤 知明 & 東京電力 \\
\cline { 2 - 3 } & 中村成春 & 大阪工業大学 \\
\cline { 2 - 3 } & 長谷川拓哉 & 北海道大学 \\
\cline { 2 - 3 } & 細川佳史 & 太平洋セメント \\
\cline { 2 - 3 } & 山田一夫 & 太平洋コンサルタント \\
\hline \multirow{4}{*}{ オブザーバー } & 荒井和喜 & 計算力学研究センター \\
\hline
\end{tabular}

*1 みやざと・しんいち/金沢工業大学 環境・建築学部環境土木工 学科 教授 (正会員)

*2 のぐち・たかふみ/東京大学大学院 工学研究科建築学専攻 准 教授 (正会員)

*3 たけわか・こうじ／鹿児島大学 工学部海洋土木工学科 教授（正 会員）
援ツールである。2006 年 11 月には, アメダスのデータ を劣化解析用に集約させた「マクロ環境情報データベー ス」，またこの情報を劣化モデルに組み込むための「環 境外力算定プログラム」, さらには簡易ではあるがコン クリート内部の物質移動現象を計算できる「簡易劣化シ ミュレーションプログラム」を組み込んだ「LECCA 1」 が，シリーズ第一弾としてリリースされた。その後も， 劣化ソフト作成委員会では表-1のメンバーが継続して, コンクリート構造物の塩害, 中性化および凍害について 劣化シミュレーションモデルの開発を進めた。その結 果, 塩害および中性化については, コンクリート中の塩 化物イオンの浸透状況あるいは中性化の進行状況をコン

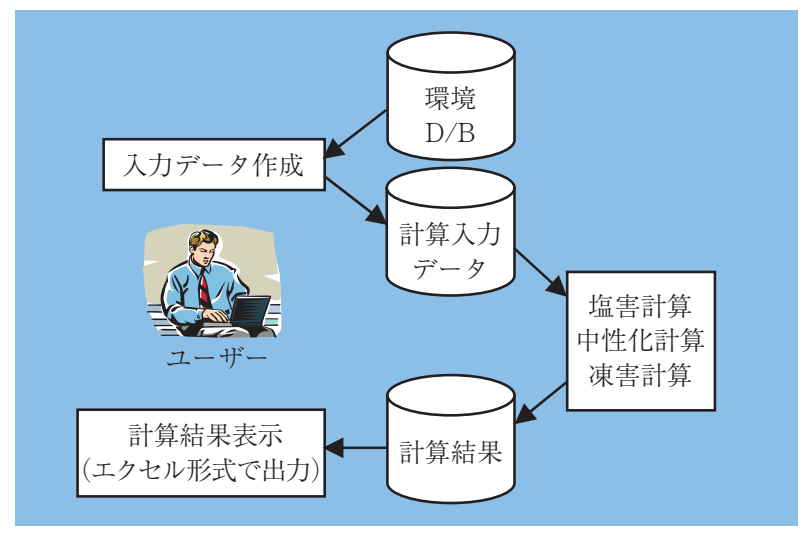

図-1ＬECCA 2 の構成とユーザー利用のイメージ

表-2 各シミュレーションの概要

\begin{tabular}{|c|c|}
\hline 項目 & 内 \\
\hline $\begin{array}{l}\text { 塩分 } \\
\text { 浸透 }\end{array}$ & $\begin{array}{l}\text { 海洋構造物と陸上構造物の両方について対応。コンクリー } \\
\text { ト中の } \mathrm{Cl}^{-} \text {の移動現象を } 2 \text { 次元 FEM により計算。 } \mathrm{Cl}^{-} \text {の } \\
\text { 固定化, 初期ひび割れの影響等についても考慮可能。 }\end{array}$ \\
\hline $\begin{array}{l}\text { 中性化 } \\
\text { 進行 }\end{array}$ & $\begin{array}{l}\mathrm{CO}_{2} \text { の拡散と } \mathrm{Ca}(\mathrm{OH})_{2} \text { の反応を考慮した } 1 \text { 次元 } \mathrm{FEM} \text { に } \\
\text { より, 中性化深さを計算。コンクリー 初期 } \mathrm{Ca}(\mathrm{OH})_{2} \\
\text { 濃度は, 設定されたコンクリートの種類, 配合, 物性等 } \\
\text { に基づく相組成モデルにより計算。 } \sqrt{t} \text { 則に基づく日本 } \\
\text { 建築学会, 土木学会提案のモデル式によっても計算可能。 }\end{array}$ \\
\hline $\begin{array}{l}\text { 鉄筋 } \\
\text { 腐食 }\end{array}$ & $\begin{array}{l}\text { 塩分浸透あるいは中性化進行に伴うコンクリート中の鉄 } \\
\text { 筋腐食に対し, 腐食発生時期, 腐食速度の変化, 腐食ひ } \\
\text { び割れの発生時期を計算。 }\end{array}$ \\
\hline $\begin{array}{l}\text { 補修 } \\
\text { 計画 }\end{array}$ & $\begin{array}{l}\text { 塩分浸透拈よび中性化進行に対し, 表面被覆や断面修復 } \\
\text { により補修した場合の効果を計算。 }\end{array}$ \\
\hline 凍害 & $\begin{array}{l}\text { 構造物の立地環境に対応する気象データ（日最低温度と } \\
\text { 相対湿度）から凍結融解サイクル（促進試験相当や } \\
\text { ASTM 相当）を算出し, 相対動弾性係数の変化から凍害 } \\
\text { 劣化の進行を計算。 }\end{array}$ \\
\hline
\end{tabular}


クリート中の細孔構造，含水状況，水和生成物との反応 などの影響を考慮して予測し，さらにコンクリート内部 の鋼材腐食についても定量評価できるモデルを構築し た。また凍害については，コンクリート内部の動弾性係 数が低下していく状況を予測できるモデルを構築した。 そこで, これらのモデルのプログラム化を進めた結果,「劣 化シミュレーションプログラム」を搭載した「LECCA 2」 が，2010 年 1 月にシリーズ第二弾としてリリースされた。 図-1に，本プログラムの構成とユーザー利用のイメージ を示す。また, 各シミュレーションの概要を表-2に示す。

本稿では，この LECCA 2 における塩害シミュレー ションについて説明し，コンクリート構造物の長期性能 照査技術の先端的取組み事例を紹介する。

\section{2. 塩害プログラム}

塩分浸透およびそれに伴う鉄筋腐食の計算フローを図-2 に示す。

まずは，立地する都市を選択する。プログラム内蔵の 環境データベースには，表-3に示す全国 153 都市の気

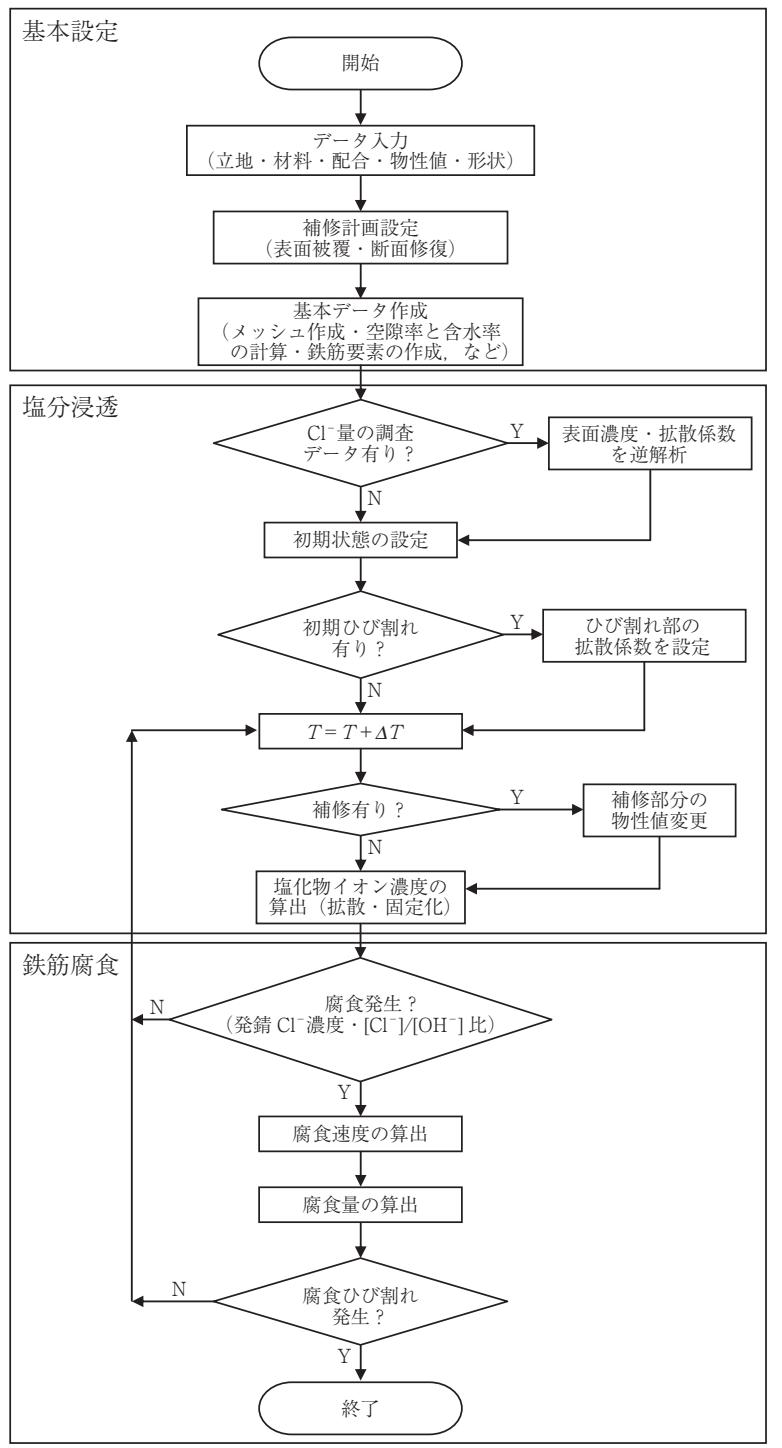

図-2＼cjkstart塩分浸透および鉄筋腐食の計算フロー
象データが、1991 年から 2000 年までの 10 年間，およ び標準年の日別データと，標準年の時別データとして保 存されている。また，表-4に示す情報を入力すること により，宇多モデル ${ }^{2)}$ や調査モデル ${ }^{3)}$ を用いて，構造物 周囲のメゾ環境における塩化物イオンの移動を計算する。

次に，使用材料や配合に関する情報を入力する。入力 值に基づき, セメントペースト部の相組成と, コンクリー 卜空隙率（ペース卜空隙率，遷移带空隙率等）を計算す る。ここで用いる相組成モデル ${ }^{4)}$ は, セメント種類, 水セ メント比, および各鉱物・混合材の反応率から, セメン トペーストの相組成（水酸化カルシウム量, C-S-H 量, $\mathrm{AFm}$ 量）を，化学量論的に求める手法である。

図-3 と図-4に示すとおり,「側面部」と「隅角部」の 2 次元形状に対する計算が可能である。特に，側面部を 対象とする場合には，任意の幅と深さの初期ひび割れを 配置できる。

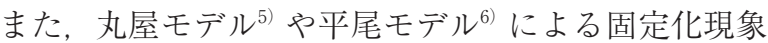
や初期ひび割れ7 ${ }^{7)}$ も も考慮し，塩分浸透を計算する。そ の後, 発錆限界塩化物イオン濃度や $\mathrm{Cl}^{-} / \mathrm{OH}^{-}$比を指標 として，腐食発生を判定する。さらに，マクロセルモデ ル ${ }^{9)}$ や実測モデル 10) 12) を用いて，腐食速度を計算する。 最後に，横関モデル13) などを用いて，腐食ひび割れの発

\section{表-3＼cjkstart選択可能な都市}

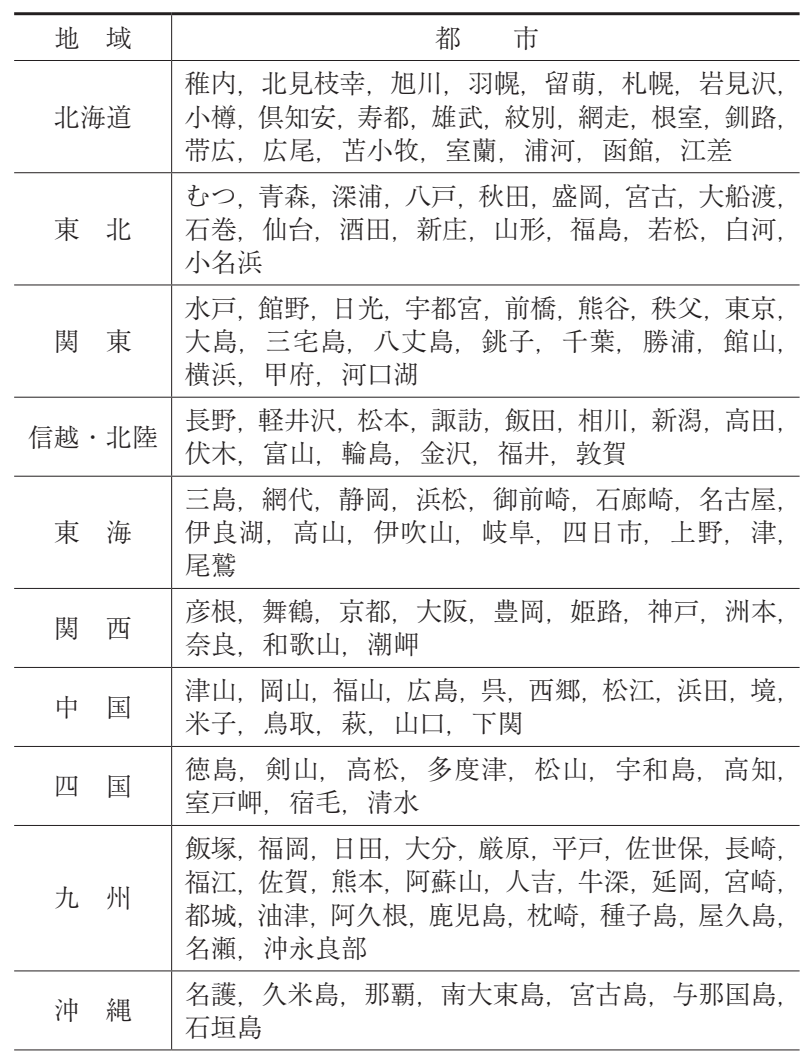

表-4＼cjkstart立地に関する入力情報

\begin{tabular}{c|c}
\hline キーワード & \multicolumn{1}{c}{ 内 容 } \\
\hline 汀線からの距離 $(\mathrm{m})$ & 汀線から構造物までの距離 \\
\hline 海面からの高さ $(\mathrm{m})$ & 海面から対象地点までの高さ \\
\hline
\end{tabular}




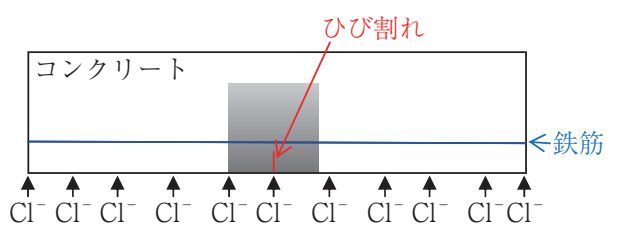

灰色部を抜き出す FEM メッシュ

不透過境界面

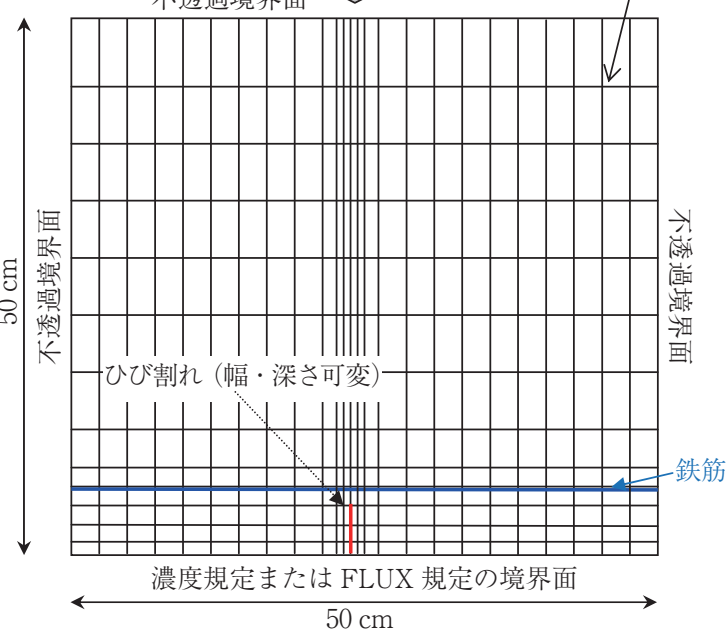

図-3＼cjkstart側面部のモデル化

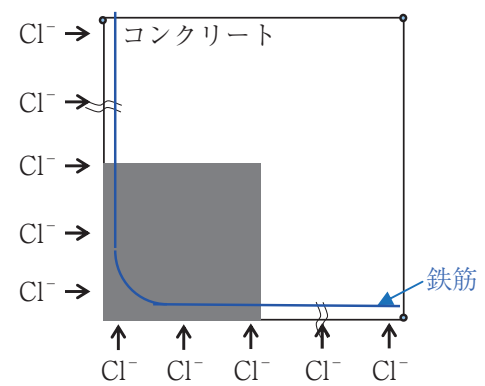

灰色部を抜き出す

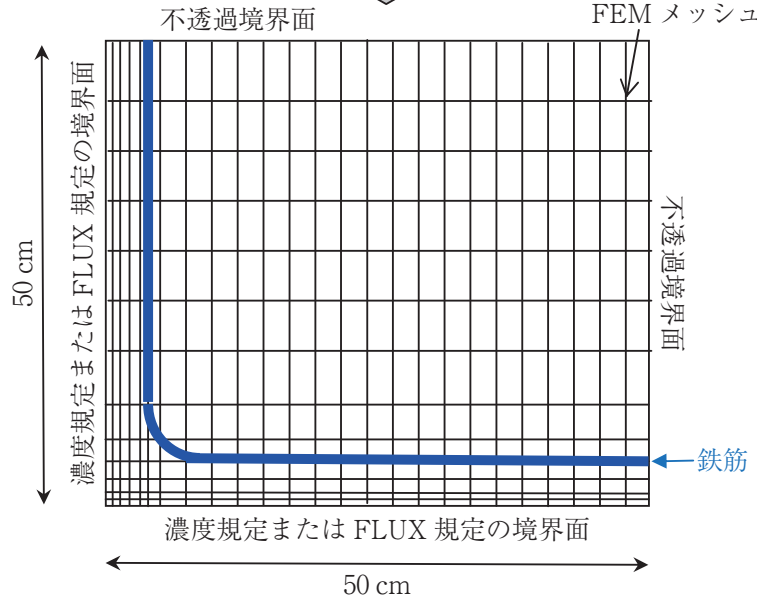

図-4＼cjkstart隅角部のモデル化

生を判定する。

3. シミュレーション例

表-5に示す条件(1)の下で，水セメント比㧍よびかぶ りが鉄筋腐食に及ぼす影響をシミュレーションする。計 算結果として，鉄筋腐食量の経時変化を図-5に示す。 これによれば，もし要求性能が50 年間にわたり腐食ひ
表-5 シミュレーションの条件

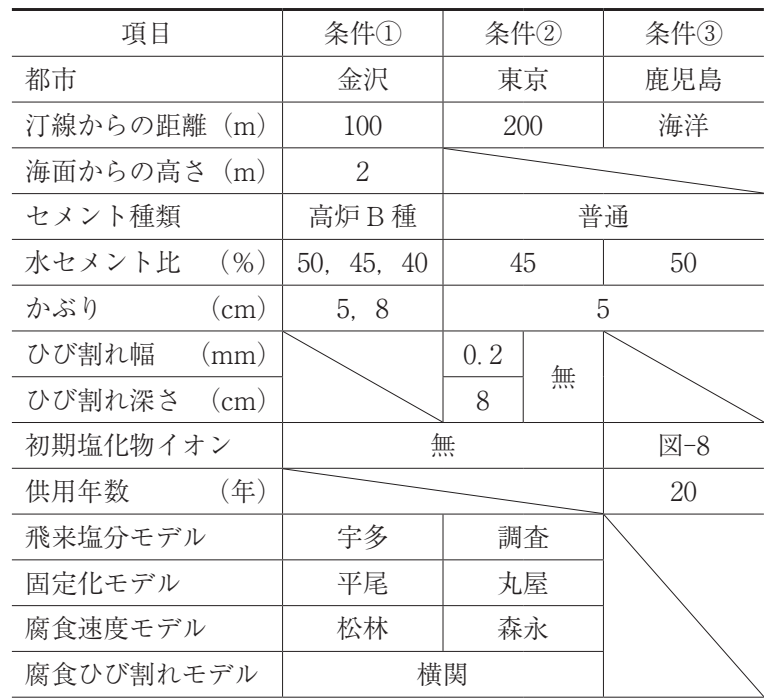

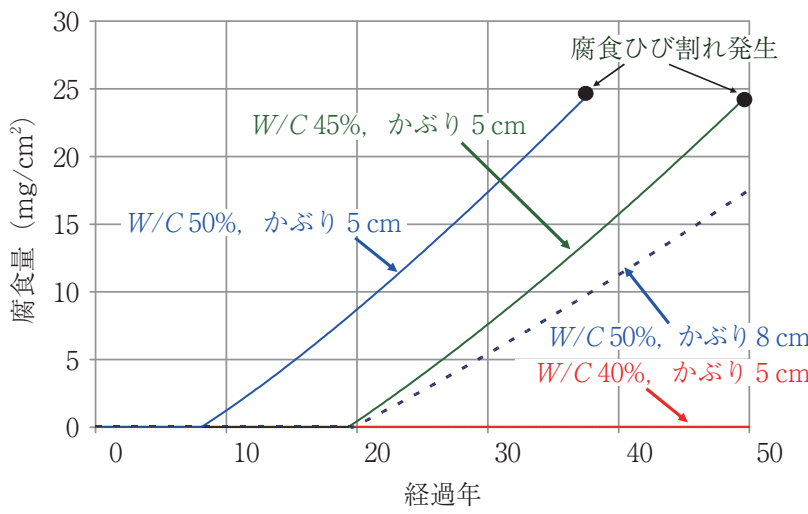

図-5 水セメント比とかぶりが鉄筋腐食量の経時変化に及ぼす影響

び割れを生じさせないことならば，ここで実施した $4 つ$ の水準の中では,「水セメント比が $40 \%$ でかぶりは $5 \mathrm{~cm} 」$ (全く腐食しない) あるいは「水セメント比が $50 \%$ でかぶりが $8 \mathrm{~cm} 」 を ，$ 長期性能照査の結果として 選択できる。

表-5 に示す条件(2)の下で, コンクリート構造物の建 設直後に初期ひび割れが生じた場合，耐久性はどの程度 に低下するかをシミュレーションする。計算結果とし て，供用 2 年目および 4 年目における，鉄筋が埋設され ている深さでの塩化物イオン濃度の分布を図-6に，初 期ひび割れの有無が鉄筋腐食量の経時変化に及ぼす影響 を図-7に示す。これらによれば，図-6に示されるよう に，塩化物イオンは初期ひび割れ部で局所的に増加す る。また，図-7に示されるように，初期ひび割れが存 在する場合には健全な場合と比較して，腐食ひび割れの 発生が約 60 年間も早まることを確認できる。

本号で特集している新設構造物に対する耐久性設計の 事例ではないが，LECCA 2 の特徵である，既設コンク リート構造物における塩化物イオン濃度の調査デー夕を 活用した余寿命シミュレーションを実施する。表-5に 示す条件(3)の下で, 図-8に示す塩化物イオン濃度の調 


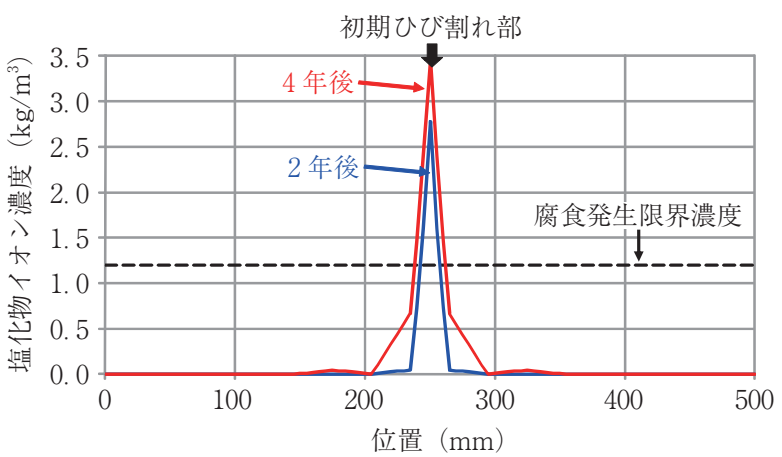

図-6 初期ひび割れが生じた場合の埋設鉄筋近傍における塩化物 イオン濃度分布

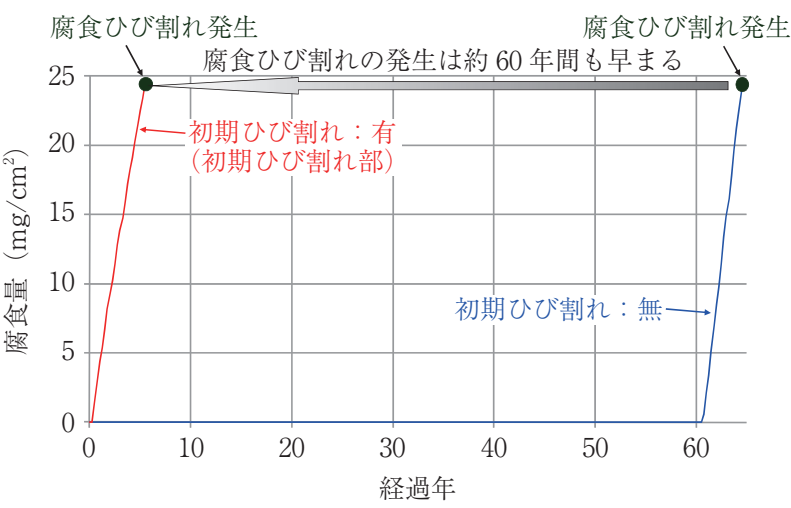

図-7＼cjkstart初期ひび割れの有無が鉄筋腐食量の経時変化に及ぼす影響

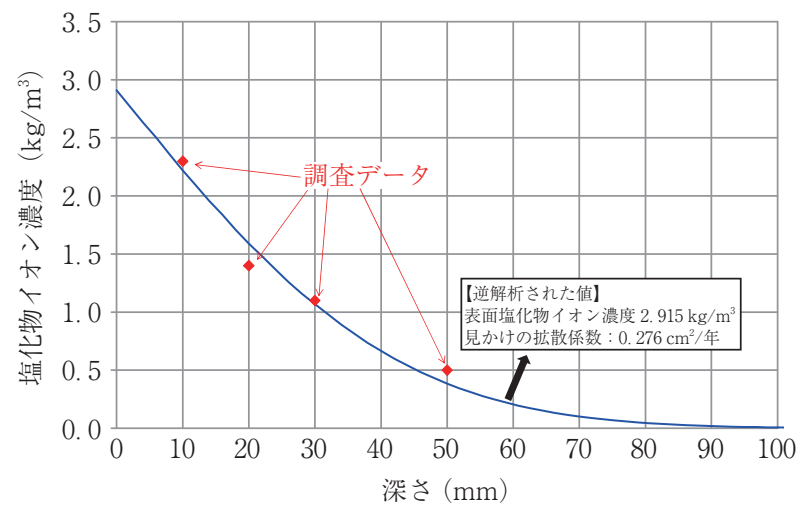

図-8＼cjkstart塩化物イオン濃度の調査データ

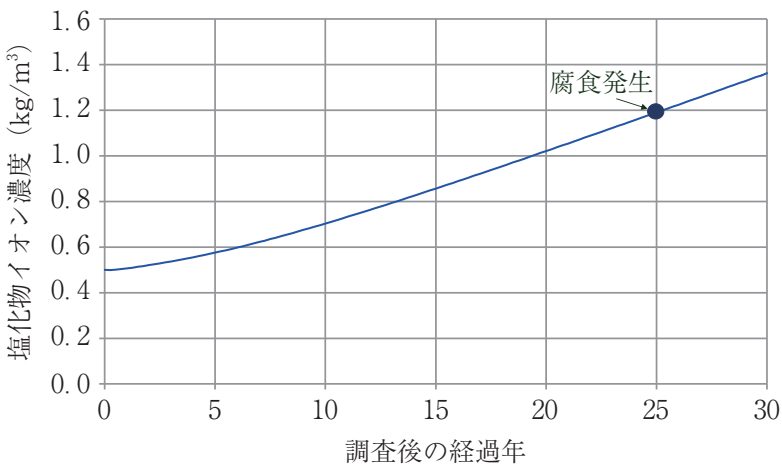

図-9＼cjkstart調査後の経過時間と埋設鉄筋近傍における塩化物イオン濃 度の関係
査データが得られた場合を仮定する。計算結果として， 調査後の経過時間と埋設鉄筋近傍での塩化物イオン濃度 の関係を図-9に示す。これによれば，25 年後程度に腐 食が始まることを予測できる。

\section{4. まと め}

日本では，高度経済成長期から 50 年間が経ち，当時 に建設された構造物の劣化が進行し始めている。このよ うな状況を踏まえ, 既に維持管理が重要視され，数多く の既設構造物に対する診断・評価が施されてきた。これ らの調査結果や研究成果を集約し，LECCA 2 が新設構 造物の長期性能をシミュレーションするソフトとして開 発された。現在, 新たなメンバーも参画して,さらなる ソフトの精緻化・高機能化を図るとともに，解析条件を 限定した簡易バージョンのリリースについても検討中で ある。

本稿の読者が，コンクリート構造物の長期性能照査技 術に興味を持ち，その一つのツールである LECCA シリー ズ (http://www.jci-net.or.jp/j/jci/study/h22plan_gijutu. html\#01）の試用を検討して頂くきっかけになれば幸い である。

\section{参考文献}

1）日本コンクリート工学協会：コンクリート構造物の長期性能照査 支援モデルに関するシンポジウム委員会報告書・論文集, 2004

2）宇多高明·小俣 篤·小西正純：海岸からの飛来塩分量の計算モ デル，海岸工学論文集，第 39 巻, pp.1051 1055, 1992

3）前田 聡・武若耕司・山口明伸：塩害データベースを用いたコン クリート中への塩化物イオン拡散の定量評価, 土木学会論文集, No.760, pp.109 120, 2004

4）坂井悦郎 · 加藤昌宏 · 浅賀喜与志 · 大門正機 : セメント水和の相 組成モデル，コンクリート工学年次論文報告集，Vol.20, No.1, pp.101 106, 1998

5）丸屋 剛·Somnuk T. 松岡康訓：コンクリート中の塩化物イオ ンの移動に関する解析的研究, 土木学会論文集, No.442, pp.81 90,1992

6) 平尾 宙·Hassan ZIBARA - 高橋晴香 - 山田一夫 : 塩化物イオン の固定に及ぼすセメント組成の影響, コンクリート工学年次論文 集, Vol.26, No.1, pp.855〜860, 2004

7) K. Takewaka, T. Yamaguchi and S. Maeda : Simulation Model for Deterioration of Concrete Structures due to Chloride Attack, Journal of Advanced Concrete Technology, Vol.1, No.2, pp.139146,2003

8）加藤絵万 · 加藤佳孝 ·魚本健人：ひび割れを有するコンクリート 中の塩化物イオン移動評価手法の提案, 土木学会論文集, No.732, pp.109 120, 2003

9）長谷川裕介・宮里心一・親本俊憲・横関康祐：ひび割れを有する 鉄筋コンクリートの腐食速度解析モデルの提案，コンクリート工 学論文集, Vol.17, No.1, pp.109〜118, 2006

10）松林裕二・桝田佳寛・笹渕優樹：塩化物を含んだコンクリート中 の鉄筋腐食速度に関する屋外暴露実験, 日本建築学会構造系論文 集, No.536, pp.9 15，2000

11）森永 繁· 入野一男·太田達見・土本凱士：腐食による鉄筋コン クリート構造物の寿命予測，コンクリート工学論文集，Vol.1 No.1， pp.177〜189，1990

12）松村卓郎·金津 努 ·西内達雄：海岸近くの大気中に位置するコ ンクリート構造物の鉄筋腐食進行評価手法, 土木学会論文集, No.634, pp.303 314, 1999

13) K. Yokozeki, K. Motohashi, K. Okada and T. Tsutsumi : A Rational Model to Predict the Service Life of RC Structures in Marine Environment, $4^{\text {th }}$ CANMET/ACI International Conference on Durability of Concrete, SP170-40, pp.777-798, 1997 